\title{
Fostering Students' Workplace Communicative Competence and Collaborative Mindset through an Inquiry-Based Learning Design
}

\author{
Rosa Huiju Chen
}

Citation: Chen, R.H. Fostering

Students' Workplace Communicative

Competence and Collaborative

Mindset through an Inquiry-Based

Learning Design. Educ. Sci. 2021, 11,

17. https://doi.org/10.3390/

educsci11010017

Received: 15 November 2020

Accepted: 25 December 2020

Published: 1 January 2021

Publisher's Note: MDPI stays neutral with regard to jurisdictional clai$\mathrm{ms}$ in published maps and institutional affiliations.

Copyright: $\odot 2021$ by the author. Licensee MDPI, Basel, Switzerland. This article is an open access article distributed under the terms and conditions of the Creative Commons Attribution (CC BY) license (https:// creativecommons.org/licenses/by/ $4.0 /)$.
Department of Foreign Languages and Literature, National I-Lan University, I-Lan 260007, Taiwan; hjchen@niu.edu.tw

\begin{abstract}
This paper illustrates the efficiency of implementing an inquiry-based teaching and learning module on the development of workplace communication competence and collaborative mindset in a college-level English as a Foreign Language context. In particular, the study highlights the 5E constructivist approach as the pedagogical foundation and addresses the effects of project-based learning scenario on students' engagement and their views in terms of "workplace habits of mind". The 5E model includes five stages: engagement, exploration, explanation, elaboration, and evaluation. In addition, teaching strategies like academia-industry cooperative teaching, industry field trip, reflective writing, and project-based presentation were incorporated into each instructional phase to emphasize the development of students' social, collaborative, and problem-solving skills. Both quantitative and qualitative data were collected including students' perceived effectiveness of engagement activities, weekly reflective journal writing and focus group interviews. The results of the study indicate that the inquiry-based teaching and learning approach had a favorable effect on the development of students' engagement and hands-on, mind-on skills such as critical thinking, collaboration, and communication.
\end{abstract}

Keywords: collaborative mindset; inquiry-based learning; workplace communicative competence

\section{Introduction}

\subsection{Workplace Communicative Competence and Collaborative Mindset}

During the era of globalization, it is a worldwide notion that English has become an international language (EIL) [1,2] or the lingua franca (ELF) [3,4]. In fact, nowadays people who communicate with English are facing to linguistic varieties and cultural diversity. More and more global organizations recruit new employees who are confident and capable to conduct intercultural communication in their second or foreign language [5]. Therefore, in order to maintain students' competitiveness in global workforce opportunities, the objectives of English language education at college level has often been considered from an interdisciplinary aspect which emphasizes the written and oral interpersonal communication skills in various social contexts like team-building, problem solving, and conflict resolution. Precisely, it is often believed by business leaders that soft skills are most important in an employee. According to a report from the Chronicle of Higher Education [6], there existed a discrepancy between students' and employers' views and the best way to prepare students' readiness to take jobs right after their graduation is to highlight the combination of both interpersonal competencies and technical skills. In short, in the context of teaching and learning English, in addition to language proficiency in public speaking and presentation skills, the importance of communication competence in the workplace has gained increasing attention in recent years.

The argument is that, in order to help students become competitive and effective in the workplace, the college-level English instruction should not only shed light on students' language proficiency, but also make efforts to enhance their professional, social, and personal 
interaction skills. This assertation can be viewed from the following two perspectives. First, from the point of view of instructional developmental approach in language education, it is evident that while developing learners' communicative competence has long been considered as a crucial factor for the success or failure of language development in the field of second/foreign language acquisition, having the competence to communicate effectively in different contexts also benefits learners' self-confidence and self-efficacy. For example, there has been a growth in the popularity of the study in applying telecollaboration or virtual exchange practices as task-based language activities to promote both linguistic and social competences $[7,8]$. However, these online intercultural interactions link language learners from different geographical locations and cultural contexts, thereby resulting in the attention of individual's collaboration skills. In fact, this kind of experiential learning approach require learners to be open-minded and adaptable which are crucial but difficult-to-teach skills in a language course.

Second, in a sense of exploring the role and characteristics of intercultural communication in the 21st century, collaboration is often regarded as an essential component of workplace communicative competence [9]. Therefore, it is also known as one of the 4Cs for $21 s t$ century learning $[10,11]$. Precisely, collaboration is the practice of working together to achieve a common goal and at some points everyone in any job position needs to work with another person. From the educational purpose perspective, only practicing collaboration in teamwork enables students understand how to address the problem-solution process and decide the best course of action. However, a common problem widely found in educational contexts is that students mainly with a fixed mindset often resist collaborative learning owing to lacking effective strategies of habits formation. For instance, components which are included in collaborative mindset vary from "Having an open-mind and willingness to hear from others", "A focus on us rather than me" to "great interactions with team members". Accordingly, it has been indicated that both disciplines and habits are necessary in the process of mind formation and it is suggested that teachers may need to engage their students in developing their habits of mind by means of learning activities design and classroom management discipline [12].

\subsection{Habits of Mind}

Habits of mind have been viewed as thinking attitudes or behaviors that affect the way when someone is dealing with the situation of problem-solving. According to Costa and Kallick [13], the habits of mind are a combination of intelligent behaviors, cognitive processes and thinking skills which can be applied to organize learning within vocational or academic settings. Meanwhile, there exist a large number of studies arguing that habits of mind should be integrated into curriculum within various contexts to assist learners to self-regulate their learning or to find solutions in the workplace [14-16]. Among these studies, the concept of engineering or geometric habits of mind in the science field has long been discussed as a means of promoting learners' level of scientific and technological literacy particularly in the STEM (Science, Technology, Engineering and Math) skills development. For example, in 2010, the National Academy of Engineering proposed three general principles for $\mathrm{K}-12$ engineering education and the third principle "engineering habits of mind" was proposed as an essential skill to construct how engineers think and act. In line with this framework, engineering habits of mind consists of several elements, namely, system thinking, creativity, optimism, collaboration, and communication [17]. As well, it is especially recognized that two of them, collaboration, and communication, occur simultaneously with problem-solving or decision-making process. Besides the above mentioned, in the field of language teaching and learning, a study conducted in Malaysia provided some insights about the connection between young ESL learners' habits of mind and their engagement in the context of collaborative reading. It has found that there are strong indications of high levels of reasoning and critical thinking in group discussion activities [18]. As well, adopting a quasi-experimental design, Alkthery and AI-Qiawi [19] investigated the effect of instructional strategy to enhance secondary grade students' pro- 
ductive habits of mind and English language persuasive writing and revealed a strong positive correlation between persuasive writing skills (Opinion or position, Reason and Support) and the productive habits of mind (Thinking flexibly, Questioning and Problem posing). Based on the above, it can be concluded that, understanding the habits of mind provides us with insights as to the nature of one individual's cognitive mechanism for the process of information gathering and conclusion drawing which can be regarded as a truly learning status.

\subsection{Inquiry-Based Teaching and the 5E Instructional Model}

It is widely acknowledged that inquiry-based teaching aims to increase students' higher-level thinking skills such as critical thinking, collaboration, and communication to meet the challenges encountered in the 21st century [20]. It especially highlights the benefits of boosting students' engagement through the learning development of hands-on, mindson skills. In addition, being presented in some pedagogical models including project-based instruction or maker-centered learning, the implementation of inquiry-based learning has been adopted in science education settings for a certain period of time. According to The Standards proposed by the National Research Council [21], inquiry is a multifaceted activity that generate a transition from textbook-dependency to a more hands-on learning approach. With respect to the efforts of transferring inquiry-based learning into practices in the classroom, previous studies had reported that applying a learning cycle approach in the classroom is necessary since it focus on constructivist principles and emphasize the investigation of phenomena. Illustrated by these studies, the $5 \mathrm{E}$ model proposed by Bybee, has been regarded a structure facilitating learning in a meaningful and powerful way, thereby creating the condition of teaching with how people learn [22,23].

Originally being generated from the constructivist-learning theory, the $5 \mathrm{E}$ instructional model consists of different stages of cognitive learning. Figure 1 provides an overview of the model. Engagement is the first phase of the cycle and it aims to access student prior knowledge which should be a motivational period. Exploration phase provides students with concrete learning experience and incorporates active exploration. Following an Explanation phase enables students to describe their understanding and articulate their reflective concepts. Elaboration phase is good opportunity to integrate learning objectives with other content areas which develop a deeper and boarder understanding. Evaluation phase allows not only teachers to assess their students, as well as students to assess their own understanding. It has been indicated that after going through this cycle and the interaction with peers or environment, students will be able to define, reorganize, elaborate, and change their original concept $[24,25]$.

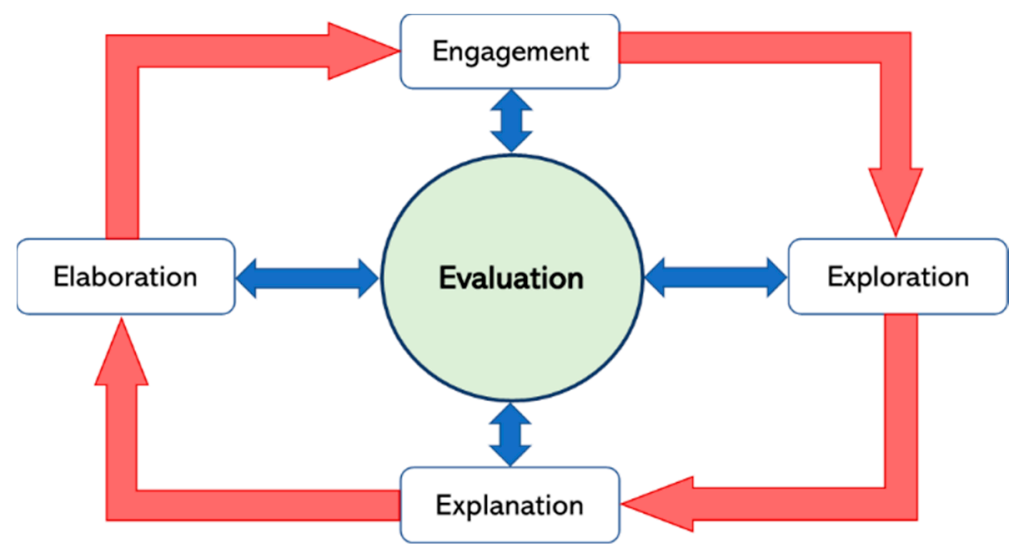

Figure 1. The 5E instructional model.

While the 5E learning cycle has been viewed as a hands-on and constructivist pedagogy, how to successfully implement this approach into a semester-long course still remains 
a challenge to instructors. With this in mind, this study proposes an instructional learning cycle that incorporates an inquiry-based teaching and learning pedagogical structure into college level English for specific purpose (ESP) course to determine if students' collaborative mindset and learning engagement would be promoted. More specifically, the $5 \mathrm{E}$ constructivist approach and the essence of project-based learning model have been adopted for the whole semester. Under the academia-industry cooperative teaching structure, students were assigned into groups to collaboratively conduct a maker-centered task and conduct an English-only forum presentation performance in class at the end of the semester. As well, while this study reported on an action research on course design that sought to determine if students' development of collaborative mindedness would be promoted, their perceptions of learning engagement are also discussed. To summarize, the current study examines the use and effectiveness of incorporating the inquiry-based, $5 \mathrm{E}$ instructional model approach in a college level EFL course in terms of promoting students' collaborative mindsets and learning engagement. The study examined the following research questions:

1. What are students' perceived effectiveness in terms of the instructional design in the inquiry-based learning classroom?

2. To what extent are students' perceptions of workplace communication competence and collaborative mindset related to their learning engagement?

3. To what degree is each habits of mind displayed in students' reflective writing?

4. What is the pedagogical implication of using the $5 \mathrm{E}$ learning cycle in the language learning domain?

\section{Materials and Methods}

\subsection{Participants}

The participants in this case study consisted of 21 EFL undergraduate students including 8 seniors, 3 sophomores and 10 freshmen at a public university in northeastern Taiwan. They were from 4 different engineering-related majors and 2 humanities-related majors with an average age of $20.18(\mathrm{SD}=1.38)$. All participants took an elective capstone course titled "Scientific English", offered by the Department of Foreign Languages and Literatures. The participants' average English proficiency level is between CEFR (The Common European Framework of Reference for Languages) B1 and C2 with an average English learning history of $11.7(\mathrm{SD}=2.68)$ years.

\subsection{Teaching Context and Instructional System Design}

This semester-long course was employed during the Spring term of 2020 and met four 50-min sessions per week for 18 weeks for a total of 72 sessions. Intentionally being designed as senior seminar to facilitate students' integrative experience in their programs, the objectives of this capstone course were well in line with the primary goal to actively engage EFL college junior and senior students through the use of project-based task and performance-based assessment. Specifically, the instructional design of this course to facilitate workplace communicative competence and collaborative mindset is the adaptation of inquiry-based learning cycle. There are two reasons for choosing the inquiry-based, $5 \mathrm{E}$ instructional model in this study. First, it is good enough for presenting students' engagement on different learning phases; second, this model highlights the nature of scaffolding in facilitating students' self-regulation and independent learning. Figure 2 shows the overview structure of the course design principles and the interconnectedness between learning objectives (21-century literacy) and target skills (workplace communicative competence and collaborative mindset). 


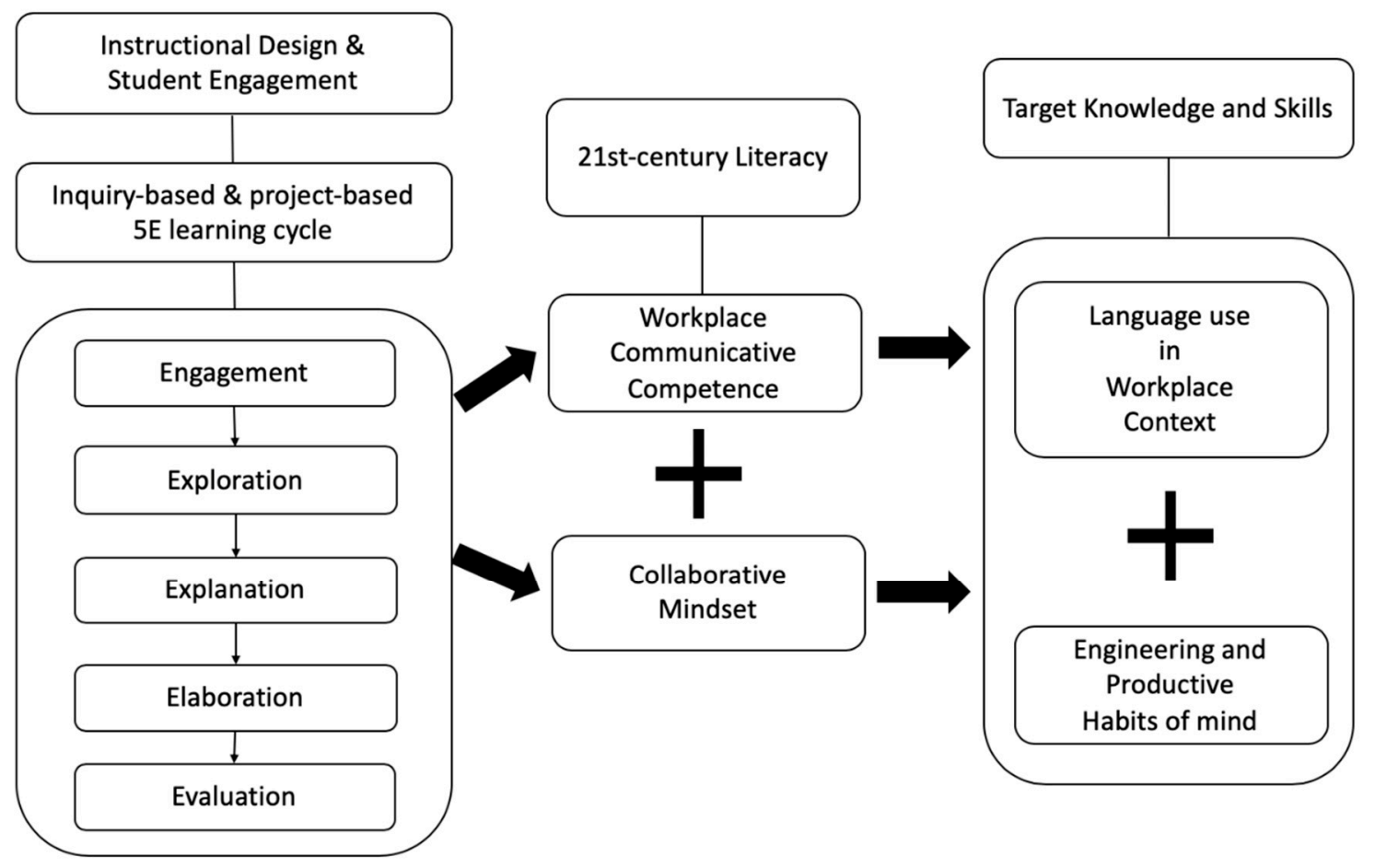

Figure 2. The overview of the research design, learning objectives and target skills.

In this study, the 5E learning cycle is adopted as a constructivist approach and pedagogical foundation to highlight the effects of project-based learning scenario in promoting students' engagement and course-based target skills. Meanwhile, this inquiry-based teaching and learning module support scaffolding, which is conceptualized as interactions between students, instructors and learning content. As such, the multimodal scaffolding strategy is used to provide support to students in various ways through combination of diverse learning activities. Table 1 illustrates that a range of different scaffolding activities are integrated into each phase of $5 \mathrm{E}$ learning cycle. Firstly, for example, at the early stage of the course, two senior software engineers in IT field who are also the course design consultant and instructional guidance on the course were invited to join the classes to introduce participants the notion of "project management" and assign them the final maker-center project. Next, in order to conduct the assigned maker-centered, collaborative project, 21 participants were grouped into 5 groups and each group member was asked to perform different roles such as the project manager, the engineer, the designer, and the project reporter. Needed tools like an Arduino I/O board plus Arduino IDE were provided to each group by the industry professionals. Then, followed by the lessons of spoken and written genres of workplace communication from the academic professor, the interaction between group members like group meeting and discussion, the introduction of the online and mobile graphic design app, participants received different scaffolding practices in term of the formation of collaborative and productive habits of mind. 
Table 1. Design phases and related learning activities.

\begin{tabular}{|c|c|c|c|}
\hline $\begin{array}{l}\text { 5E Phase } \\
\text { (Scaffolding Tools) }\end{array}$ & Learning Activities for Each Phase & $\begin{array}{l}\text { Mechanisms for } \\
\text { Encouraging Collaboration }\end{array}$ & $\begin{array}{l}\text { Language and Mindset } \\
\text { Assessment Criteria }\end{array}$ \\
\hline $\begin{array}{l}\text { Engagement } \\
\text { (Instructional guidance, } \\
\text { Curiosity and deep } \\
\text { thinking raising) }\end{array}$ & $\begin{array}{l}\text { Industry professionals } \\
\text { introduce the project-based, } \\
\text { maker-centered task and } \\
\text { provide the materials } \\
\text { (Arduino I/O board + } \\
\text { Arduino IDE) to each group. } \\
\text { Students are grouped to } \\
\text { explore the Electronic } \\
\text { Prototyping Kits and Tools. }\end{array}$ & $\begin{array}{ll}\text { - } & \text { Create interest } \\
\text { - } & \text { Generate curiosity }\end{array}$ & $\begin{array}{ll}\text { - } & \text { Reading } \\
\text { - } & \text { Group meeting } \\
\text { - } & \text { Creating, imagining, and } \\
& \text { innovating (HOM) }\end{array}$ \\
\hline
\end{tabular}

- $\quad$ Students collaborate with others to gather idea and engage in practice with materials and tools.

Exploration (Inquiry questions, Trial and error)

- $\quad$ The academic professor asks questions about what students are creating and listen to students' ideas
- $\quad$ Refine ideas from each group member

- Work together to design through investigation
- Oral discussion

- $\quad$ Reflective writing

- Connect prior knowledge to new content (HOM)
- $\quad$ Students are encouraged to explain their creative concepts and designs in their own words.

Explanation

(Inquiry questions,

Idea articulation)

- $\quad$ The academic professor asks questions that help students to be specific in their explanations.
Encourage students to explain their concepts to group members and reach an agreement
- Oral discussion

- Meeting minute wiring

- $\quad$ Striving for accuracy (HOM)
- $\quad$ The academic professor help students how to draw

Elaboration

(Feedback provision, Reasoning verbalization) conclusions from data.

- Students learn to connect the design solution to a real-world problem and refine their ideas.
Encourage students to share their design to other groups and get some feedbacks.
- $\quad$ Oral practice (show and tell)

- $\quad$ Reflective writing

- $\quad$ Learning to be persisting (HOM)
- $\quad$ The instructor arranges a presentation to help students answer questions about their design and explain their

Evaluation

(Feedback provision, Self-assessment) thinking

- Both academic professor and industry professionals assess students' understanding and performance together
Students work together to demonstrate what they are able to do
- $\quad$ Poster design and creation

- Q\&A Oral presentation

- Remaining open to continuous learning (HOM) 
As indicated in Table 1, drawing on social constructivism for theoretical support, the different learning activities at each phase create innovative ways of interaction and collaboration among students to finish the group project. With respect to the pedagogic approach for developing collaborative habits of mind and the reflective activities after completing the inquiry tasks at each phase, some collaborative mechanism rooted in the learning activities, and the assessment criteria are also listed in Table 1.

\subsection{Data Collection and Analysis}

Both quantitative and qualitative data were collected and the measuring tools adopted in this study included a questionnaire of learning engagement and satisfaction for measuring students' perception of learning activity, the summative assessment of the group project, bi-weekly reflective journal writing for personal learning experience, as well as a focus group interview at the end to the course. To address the first and second research questions, a 45-item questionnaire of learning engagement originated from the National Survey of Student Engagement (NSSE) [26] as well as participants' perceived usefulness of learning activities were analyzed. In addition, the summative assessment of the group project comprising of written (poster-design) and oral presentation (show and tell) activity formats was used for triangulation. To deal with the third research question, the reflective journal writing was examined through a rubric adopted from Marzano [27] to get a deep understating of what kinds of habits of mind perceived and exhibited in learning process. Convenience sampling and a semi-structured interview format was used. Eight individuals volunteered to be interviewed. Each interview was conducted face-to-face and took about $20 \mathrm{~min}$ for each participant. The results of the interview were also compared with participants" learning engagement and reflective writing.

\section{Results and Discussion}

The analysis was conducted in two parts. The first part of the results addresses the first and second research questions, how participants engage in the inquiry-based learning design course by providing an overall picture of their perceived usefulness of different activities and the correlation with learning engagement. The second part of the results section report on the findings related to the third research question examining the evidences in habits of mind formation.

\subsection{Perceived Benefits of Inquiry-Based Learning Design}

To address the first question (participants' perceived benefits of inquiry-based learning), an end-of-semester survey was assessed using questions that focus on classroom-based engagement to give an overview of the effectiveness in terms of the instructional design to promote EFL students' engagement in the inquiry-based learning classroom. These data are summarized in Table 2 and it is found that students generally agree to the effectiveness of the inquiry-based learning activities, for example, $81.3 \%$ of them agreed and strongly agreed that the group project task was greatly helpful and $87.5 \%$ of them agreed and strongly agreed that they had learned a great deal on the topic of habits of mind, implying that students were generally positive about having the learning outcomes as set by the course design. When it comes to the cultivation of workplace competitive competence and collaborative mindset, the vast of majority of participants reported having achieved a high level of project management skills and problem-solving ability, both with a percentage of $93.8 \%$. 
Table 2. Students' perceived effectiveness of engagement activities.

\begin{tabular}{lll}
\hline \multicolumn{1}{c}{ Survey Items } & \multicolumn{1}{c}{ Strongly Agree } & \multicolumn{1}{c}{ Agree (Total) } \\
\hline $\begin{array}{l}\text { Q: Learning the topic of “Habits of Mind” } \\
\text { really helps me a lot. }\end{array}$ & $56.2 \%$ & $31.2 \%(87.5)$ \\
$\begin{array}{l}\text { Q: Group project task really helps me a lot. } \\
\text { Q: Reflective writing activity really helps me }\end{array}$ & $62.5 \%$ & $18.7 \%(81.3)$ \\
$\begin{array}{l}\text { a lot. } \\
\text { Q: This course motivates me and promotes my } \\
\text { confidence in English learning. }\end{array}$ & $52.5 \%$ & $12.5 \%(75.0)$ \\
$\begin{array}{l}\text { Q: This course helps me acquire knowledge in } \\
\text { a deeper way. }\end{array}$ & $75.0 \%$ & $31.2 \%(81.2)$ \\
$\begin{array}{l}\text { Q: The instruction from the industry } \\
\text { professionals helps me a lot. }\end{array}$ & $56.2 \%$ & $12.5 \%(87.5)$ \\
$\begin{array}{l}\text { Q: This course helps me acquire } \\
\text { problem-solving ability. }\end{array}$ & $75.0 \%$ & $31.3 \%(87.5)$ \\
$\begin{array}{l}\text { Q: This course prepares me for my career } \\
\text { development. }\end{array}$ & $75.0 \%$ & $18.8 \%(93.8)$ \\
$\begin{array}{l}\text { Q: This course cultivates my workplace } \\
\text { communicative competence. }\end{array}$ & $81.2 \%$ & $18.8 \%(93.8)$ \\
$\begin{array}{l}\text { Q: This course cultivates my project } \\
\text { management skill. }\end{array}$ & $68.7 \%$ & $12.5 \%(93.8)$ \\
\hline
\end{tabular}

\subsection{Correlation between the Perceived Benefits and Learning Engagement}

To explore whether there was significant connection between students' learning engagement and items among inquiry-based learning design, Pearson correlation coefficient was used and some preliminary findings were illustrated in the following table. Values of all significant correlations are given with degree of significance indicated ${ }^{*} p<0.05$, and $\left.{ }^{* *} p<0.01\right)$. First, as shown in Table 3 positive correlation was found between perceived importance of English in career development and English learning attitude $(r=0.78, p<0.01)$, indicating that students who enrolled in this elective course were those who kept a higher motivation in studying English and had better career development expectations. In addition, positive correlation was found between problem solving skill with learning engagement $(r=0.54, p<0.05)$ and with workplace communication $(r=0.57, p<0.05)$. Obviously, the results also showed that learning engagement was positive related to several items like mindset change, reflective writing task, project management skill and overall satisfaction to the course (item $8,9,11,12$ ).

\subsection{Evidence of Collaborative Habits of Mind}

The third research question sought to determine which types of habits of mind generated in the learning process lead to students' perceived helpfulness in achieving learning outcomes. A comparison of the types of habits of mind displayed from students' reflective writing and interviewed (see Figure 3) revealed that "Thinking interdependently" and "Managing impulsivity" were the most commonly reported habit, followed by "Thinking flexibly", "Applying past knowledge to new situation", and "Striving for accuracy". Results from the above data indicated that it is considered that the inquiry-based learning tasks had positive effects in fostering students' higher order thinking skills. 
Table 3. Correlation matrix of sense of learning engagement with other variables.

\begin{tabular}{|c|c|c|c|c|c|c|c|c|c|c|c|c|}
\hline & 1 & 2 & 3 & 4 & 5 & 6 & 7 & 8 & 9 & 10 & 11 & 12 \\
\hline 1 English learning attitude & & & & & & & & & & & & \\
\hline 2 Career development & $0.78^{* *}$ & & & & & & & & & & & \\
\hline 3 Problem solving skill & $0.53 *$ & 0.02 & & & & & & & & & & \\
\hline 5 Learning engagement & $0.55^{*}$ & 0.11 & $0.54^{*}$ & 0.43 & & & & & & & & \\
\hline 6 Workplace communication & 0.37 & 0.33 & $0.57^{*}$ & 0.44 & 0.47 & & & & & & & \\
\hline 7 Belonging to groups & 0.02 & 0.00 & $0.65^{* *}$ & $0.77^{* *}$ & 0.47 & $0.51 *$ & & & & & & \\
\hline 8 Overall satisfaction & 0.00 & 0.17 & 0.76 & $0.71^{* *}$ & $0.54 *$ & 0.61 * & $0.62 * *$ & & & & & \\
\hline 10 Interaction with peers & 0.33 & 0.22 & 0.55 & 0.40 & 0.38 & 0.46 & $0.55 *$ & 0.38 & $0.57 *$ & & & \\
\hline 11 Mindset change & 0.45 & 0.20 & 0.03 & 0.21 & $0.86^{* *}$ & 0.00 & 0.37 & 0.48 & $0.79^{* *}$ & 0.30 & & \\
\hline 12 Project management skill & 0.19 & 0.11 & 0.23 & 0.27 & $0.68^{* *}$ & 0.32 & 0.30 & $0.59 *$ & $0.93^{* *}$ & 0.63 ** & $0.68^{* *}$ & \\
\hline
\end{tabular}




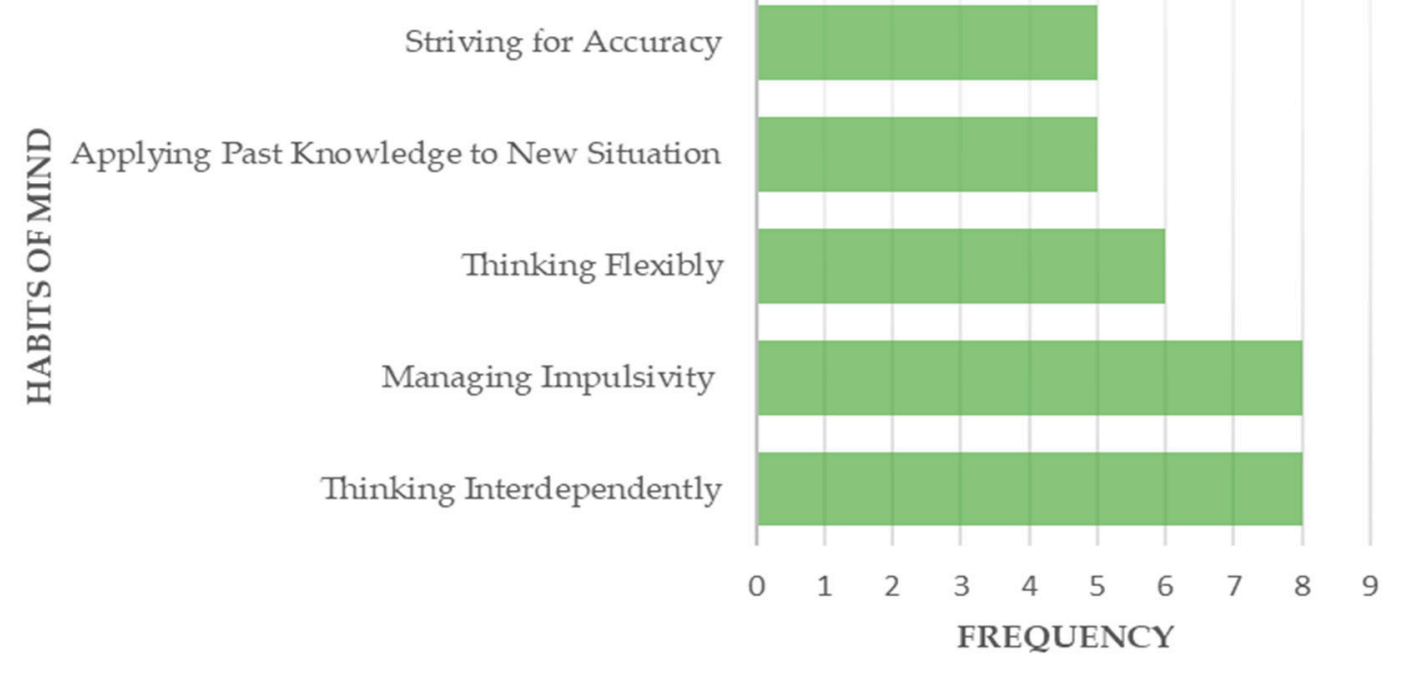

Figure 3. Students' habits of mind displayed in the reflective writing.

\subsection{Interviews with the Students}

To further understand students' perceptions of the inquiry-based learning activities, eight students were randomly selected for interviews. From the interview results, it can be concluded that students considered the helpfulness of the inquiry-based learning design as "enhancing achievement on English learning", "improved communication skills" and "chances to work collaboratively in a team". In terms of "enhancing achievement on English learning", some shared the common opinion that such a learning approach was appealing and through the implementation of the designed activities, their English proficiency improved both on written and spoken genres in the workplace context. For example, one student mentioned that "Comparing to myself before, I found I become braver to speak English in public." The other student also indicated that "My English ability is improved and I understand myself more". Regarding "improved communication skills," 6 students reported that they learned how to organize their thinking systematically before communicating effectively to others with the project-based team-working experience. For example, one students mentioned that "The learning task enables me to work collaboratively with students from different majors and surprisingly we work successfully. It is quite a sense of achievement."

\section{Discussion}

\subsection{The Applicatioin of Inquiry-Based Learning and Teaching for Developing Habits of Mind}

The results of this study showed that the inquiry-based learning design was conducive to improving EFL students' workplace communicative competence as well as their collaborative mindset. Specifically, it had been asserted that the implementation of a project-based learning pedagogy by the $5 \mathrm{E}$ constructivist approach was beneficial to promoting students' learning engagement and workplace habits of mind. First, students had to work in a team and negotiate with peers from other majors to gradually achieve the goal. Such a collaboration process provided students great opportunities to understand more about the real workplace context. Therefore, it is indicated that most participants agreed that the project-based learning and assessment conducted in this class effectively motivated them and promoted their confidence in English use at workplace. This is in accordance with the findings of Huang et.al. [28] due to argument that authentic activities are critical for 
promoting inquiry-based learning and problem-solving skill. Second, scholars in educational settings have highlighted the fact that student engagement in schooling process is an important factor to predict their achievement and sustainability $[29,30]$. In fact, it is the engagement phenomenon that evidenced students' involvement in conducting learning activities such as active participation in class, interaction with instructors and collaborations with peers. This can be found from one of the major findings of this study, showing that learning engagement was positively related to several successful learning outcomes. Finally, from the perspective of developing students' habits of mind, it is surprising that most students reported that they gained a lot in learning habits of mind. Particularly, the teaching strategies combining the exercise of habits of mind promote creativity and strategic thinking, thereby, student who sharpens these tools will be well-equipped for successful future. This is in accordance with the findings of previous study [31], indicating that students strongly perceived the value and objectives of the course design, particularly in terms of project management skill and collaborative mindset related to workplace. In addition, the results of this study were also consistent with the Interest-Driven Creator (IDC) theory which was developed by a group of Asian researchers. [32,33]. The IDC theory, consisting of three anchored concepts, namely, interest, creation, and habit, emphasized the importance of a habit building loop during students' learning process. It is believed that the IDC theory will enable students to develop their interests in learning and such habitual behavior of creating knowledge can be sustained lifelong.

\subsection{Limitations and Challenges for the Current Design and Implications for Future Research}

The implication of this study can be examined both from research and practice. First, the use of the inquiry-based learning model promotes students' emotional and behavioral engagements, thereby enhance their cognitive engagement. In addition, it has been asserted that learning engagement is definitely an important factor for the cultivation of habits of mind. Secondly, for some students, the effectiveness of task like reflective writing may not stay consistent from that of other task like project conducting. It is still worthwhile for teachers to implement an alternative approach to make learning more engaged, especially for making the habits of mind explicit to students. Overall, while the results of this study indicated that the format of the inquiry-based learning provided more opportunities for students to engage in project-based learning and effectively increase their confidence, the findings are mainly based on the data collected from a single course. Therefore, more studies on the application of inquiry-based learning design and teaching for different habits of mind for various learning contexts need to be conducted in the future.

\section{Conclusions}

In this 21st century, since technological and social changes have never been as rapid as before, the educational practices meet the challenges to be evolving and innovating. Under the premise of the rapidly developing of information technology, how to promote and measure students' learning engagement and outcome will continuingly be the next challengeable issue for EFL teachers. Consequently, there has been a lot of conversation and consternation around one important issue: How can we best prepare college students for the world of work? This study sought to investigate inquiry-based learning cycle in sense of students' mindset change in an EFL context in order to identify the connection of inquiry learning and instructional design. Overall, the results show great promise for the inquiry $5 \mathrm{E}$ model. Combined with a project-based scenario, students engage in active learning which effectively enhance their learning motivation and increase collaborative mindsets. This result is consistent with the findings of previous studies [34,35]. In addition, this study adds support to the notion that students' course work performance was positively related to their level of learning engagement and task performance. Particularly, in addition to the academic performance like English language proficiency, other competences related to the survival or success of workplace is the major concern of students nowadays. Therefore, the 
5E model allows educators to create a unique learning experience for students and they will easily experience the reform-based teaching practices.

Funding: This research was funded by the Center for Teaching and Learning of National I-Lan University.

Institutional Review Board Statement: Not applicable.

Informed Consent Statement: Informed consent was obtained from all subjects involved in the study.

Data Availability Statement: All data generated or analysed during this study are included in this published article.

Conflicts of Interest: The author declares no conflict of interest.

\section{References}

1. Porto, M.; Houghton, S.; Byram, M. Intercultural citizenship in the (foreign) language classroom. Lang. Teach. Res. 2017, 22, 1-15. [CrossRef]

2. Wong, C. Teaching Pronunciation to Learners of English as a Lingua Franca. In English Language Teaching Today; Renandya, W., Widodo, H., Eds.; Springer Nature AG: Cham, Switzerland, 2016; pp. 241-255.

3. Jenkins, J. Current Perspectives on teaching World Englishes and English as an international language. TESOL Q. 2006, 40, 157-181. [CrossRef]

4. Jenkins, J. English as a Lingua Franca: Interpretations and attitudes. World Engl. 2009, 28, 200-207. [CrossRef]

5. Jackson, J. Preparing students for the global workplace: The impact of a semester aboard. Lang. Inter. Com. 2015, 15, 76-91. [CrossRef]

6. Fabris, C. College Students Think They're Ready for the Work Force. Employers Aren't so Sure. 2015. Available online: https:/ / www.chronicle.com/article/college-students-think-theyre-ready-for-the-work-force-employers-arent-so-sure (accessed on 2 November 2020).

7. Vurdien, R. Videoconferencing: Developing students' communicative competence. J. Foreign Lang. Educ. Technol. 2019, 4, $269-298$.

8. O'Dowd, R. From telecollaboration to virtual exchange: State-of-the-art and the role of UNICollaboration in moving forward. J. Virtu. Exch. 2018, 1, 1-23. [CrossRef]

9. Martin, J.; Nakayama, T. Reconsidering intercultural (communication) competence in the workplace: A dialectical approach. Lang. Intercult. Commun. 2015, 15, 1-16. [CrossRef]

10. Saleh, S. 4Cs in the EFL Classroom. 2019. Available online: https:/ /www.researchgate.net/publication/336667149_4Cs_in_the_ EFL_Classroom (accessed on 2 November 2020).

11. Ladegaard, H.; Jenks, C. Language and intercultural communication in the workplace: Critical approaches to theory and practice. Lang. Intercult. Commun. 2015, 15, 1-12. [CrossRef]

12. Loveland, T.; Dunn, D. Teaching engineering habits of mind in technology education. Technol. Eng. Teach. 2014, 73, 18.

13. Costa, A.; Kellick, B. Discovering and Exploring Habits of Mind; ASCD: Alexandria, VA, USA, 2000.

14. Costa, A.; Kellick, B. Learning and Leading with Habits of Mind: 16 Essential Characteristics for Success; ASCD: Alexandria, VA, USA, 2009.

15. Lippard, C.; Lamm, M.; Kristina, M.; Choi, J. Pre-engineering thinking and the engineering habits of mind in preschool classroom. Ear Child Educ. J. 2019, 47, 187-198. [CrossRef]

16. Hew, K.; Cheung, W. Student facilitators' habits of mind and their influences on higher-level knowledge construction occurrences in online discussions: A case study. Innov. Educ. Teach. Int. 2011, 48, 275-285. [CrossRef]

17. National Academy of Engineering. NAE Annul Report. 2010. Available online: https://www.nae.edu/51959/NAE-AnnualReport-2010 (accessed on 25 October 2020).

18. Maria, S.; Goh, H.; Kamaruzaman, J. Habits of Mind in the ESL Classroom. Eng. Lang. Teach. 2013, 6, 130.

19. Alkthery, A.; Dalal, A. The effect of SPAWN strategy in developing persuasive writing skills and productive habits of mind. Arab. World Eng. J. 2020, 11, 459-481. [CrossRef]

20. Prokes, C. Inquiry-based planning and teaching for the 21 century: Impacts of the 5E model in social studies. Ohio Soc. Stud. Rev. 2009, 45, 15-23.

21. National Research Council (NRC). National Science Education Standards; No. National Academy Press: Washington, DC, USA, 2009.

22. Duran, L; Duran, E. The 5E instructional model: A learning cycle approach for inquiry-based science teaching. Sci. Educ. Rev. 2004, 3, 49-58.

23. Rodriguez, S.; Allen, K.; Harron, J.; Qadri, S. Making and the 5E Learning Cycle. Sci. Teachnol. 2019, 86, 48-55. [CrossRef]

24. Bybee, R. Achieving Scientific Literacy; Heinemann: Oxford, UK, 1997.

25. Bybee, R.; Taylor, J.; Gardner, A.; Scotter, P.V.; Powell, J.C.; Westbrook, A.; Landes, N. The BSCS 5E Instructional Model: Origins and Effectiveness; BSCS: Colorado Springs, CO, USA, 2006.

26. Kuh, G. The National Survey of Student Engagement: Conceptual and Empirical Foundations. New Dir. Inst. Res. 2009, 141, 5-20. [CrossRef] 
27. Marzano, R. A Different Kind of Classroom: Teaching with Dimensions of Learning; Association for Supervision and Curriculum Development: Alexandria, VA, USA, 1992.

28. Hwang, G.; Chiu, L.; Chen, C. A contextual game-based learning approach to improving students' inquiry-based learning performance in social studies courses. Comput. Educ. 2015, 81, 13-25. [CrossRef]

29. Hampel, R.; Pleines, C. Fostering student interaction and engagement in a virtual learninge: An Investigation into activity design and implementation. CALICO J. 2013, 30, 342-370. [CrossRef]

30. Kuh, G. What student affairs professionals need to know about student engagement. J. Coll. Stud. Dev. 2009, 50, 683-706. [CrossRef]

31. Garderen, D. Using the 5E instructional model in an online environment with pre-service special education teachers. J. Sci. Educ. 2020, 23, 8. [CrossRef]

32. Wong, L.H.; Chan, T.W.; Chen, W. IDC theory: Interest and the interest loop. RPTEL 2020, 15, 1-16. [CrossRef]

33. Chan, T.W.; Looi, C.K.; Chen, W.; Wong, L.H.; Chang, B.; Liao, C.C.Y.; Ogata, H. Interest-driven creator theory: Towards a theory of learning design for Asia in the twenty-first century. J. Comput. Educ. 2018, 5, 435-461. [CrossRef]

34. Cañado, P.; María, C. Intercultural communication in the global workplace: The case of multicultural teams in Spain. Cull. Lane Rep. 2007, 4, 185-202.

35. O'Neill, M. How to Achieve Collaboration in the Workplace. Promises at Work. 2018. Available online: https://www.samewave. $\mathrm{com} /$ posts/how-to-achieve-effective-collaboration-in-the-workplace (accessed on 17 October 2020). 